\title{
Change in the Southern Ocean: Responding to Antarctica
}

Lionel Carter ${ }^{1}$ and Giuseppe Cortese ${ }^{2}$

'Antarctic Research Centre, Victoria University, Wellington, New Zealand; lionel.carter@vuw.ac.nz

${ }^{2}$ Geological and Nuclear Sciences, Lower Hutt, New Zealand; g.cortese@gns.cri.nz

Antarctica exerts a strong influence on the Southern Ocean, where sea surface temperatures, ocean frontal systems and icebergs respond directly to glacial/interglacial- to millennial-scale changes. These responses, however, can differ between ocean basins, due to differences in basin morphology, circulation and climate.

Precisely fifty years ago, in a 3-page letter to Deep-Sea Research, Henry Stommel (1958) highlighted the role played by Antarctica in driving the oceans' abyssal circulation. Since then, many studies of the present and past ocean have redefined the close links between Antarctica and the Southern Ocean, and their influence on the global ocean and climate. To highlight those links, we briefly review Antarctica's impact on the surface of the Southern Ocean at glacial-interglacial (G-I) and millennial timescales.

The Southern Ocean is a sea of superlatives. It is dominated by the longest (24,000 km), largest (transport of $\sim 13710^{6}$ $\mathrm{m}^{3} \mathrm{~s}^{-1}$ ) and only current to link the major oceans-the Antarctic Circumpolar Current (ACC) (Fig. 1). This complex system of flows is driven mainly by the westerly zonal winds. Much of its flow today is concentrated along several ocean fronts that also define the distribution of surface waters and include, from north to south, the Subantarctic, Polar, Southern, and Boundary Fronts (e.g., Orsi et al., 1995).

\section{Riding the G-I Cycle}

A wide range of proxies for sea surface temperature (SST) reveal strong glacial cooling at orbital frequencies (e.g., Barrows et al., 2007; Cortese et al., 2007; Gersonde et al., 2005; Howard and Prell, 1992; Pahnke and Sachs, 2006). Ocean cooling was most pronounced around $40-46^{\circ} \mathrm{S}$ during major glaciations of Marine Isotope Stages (MIS) $2,6,8,10$ and 12 , when SSTs were $4-6^{\circ} \mathrm{C}$ lower than present. Such temperature differences were reduced southwards. By comparison, the peak interglacial periods of MIS $5 \mathrm{e}$ and 11 had SSTs up to $3^{\circ} \mathrm{C}$ warmer than present.

The variability in SSTs between these periods and the present is associated with meridional shifts of ocean fronts coincident with the growth and decay of the cryosphere, and the migration of westerly winds. Glacial periods witnessed major expansions of ice sheets and winter sea ice, which extended $3-8^{\circ}$ of latitude northward into the Atlantic, 7-10 into the Indian Ocean and possibly $\sim 2-5^{\circ}$ into the Pacific Ocean. This expansion was accompanied by an equatorward displacement of the westerly winds and ocean fronts. In

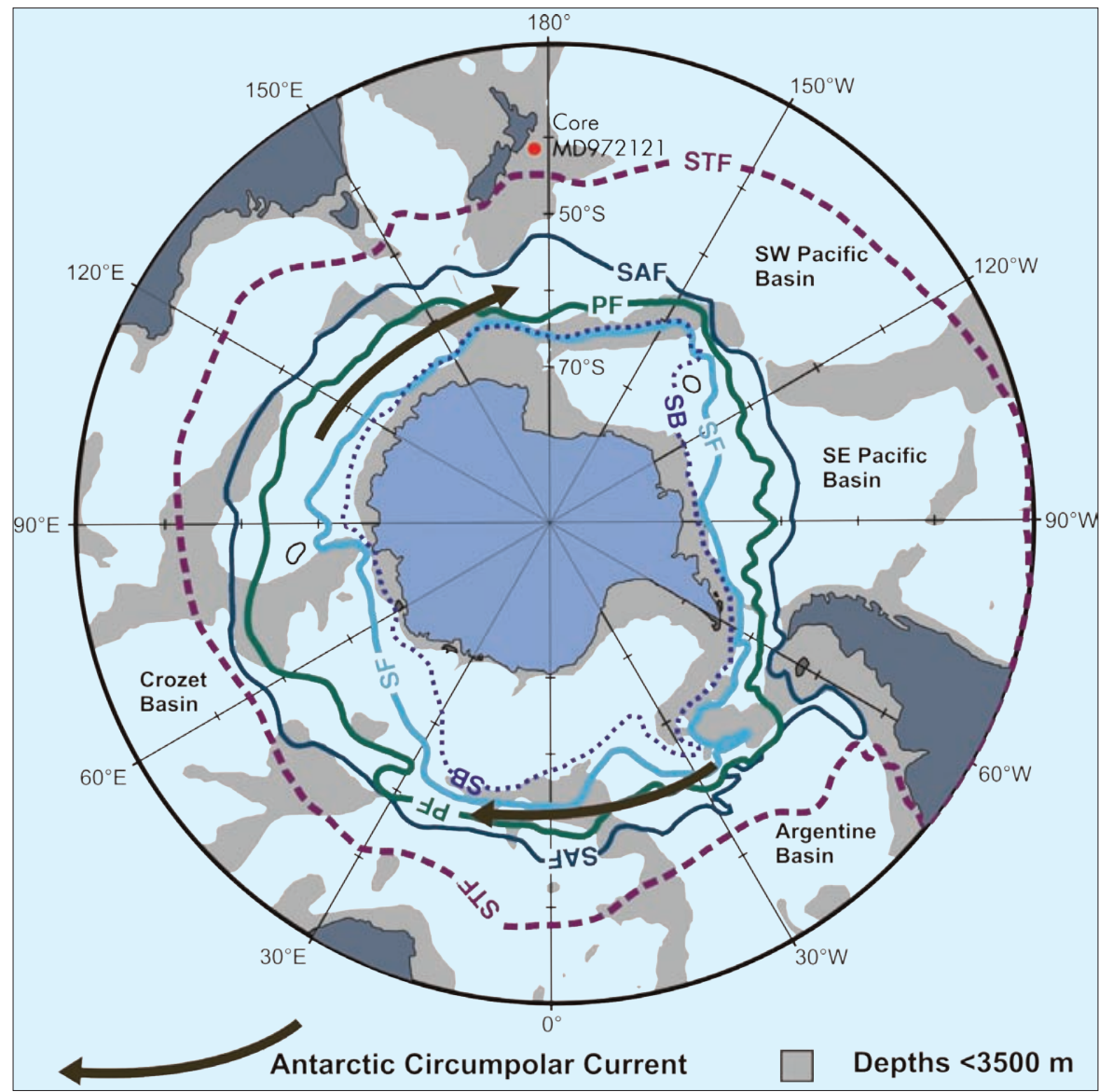

Figure 1: The Southern Ocean and its frontal systems that include the Subtropical (STF; purple dashed line) and Subantarctic (SAF; dark blue line), Polar (PF; green line), Southern (SF; light blue line) and Southern Boundary (SB; purple dotted line) Fronts, with the Antarctic Circumpolar Current (black arrows) constrained between the SAF and SB. Red dot indicates location of core MD97 2121.

the open Southern Ocean, away from shallow bathymetry, the Polar Front moved $4^{\circ}$, 5-10 and $2-3^{\circ}$ into the Atlantic, Indian and Pacific sectors, respectively, during the LGM. At the same time, the Subantarctic Front shifted $4-5^{\circ}$ and $5-10^{\circ}$ into the Atlantic and Indian oceans. In contrast, the Subtropical Front displayed smaller, $\sim 2-5^{\circ}$ shifts, possibly the result of blocking by the subtropical gyres in the main ocean basins. This could compress and intensify oceanographic gradients at the northern limit of the Southern Ocean (Gersonde et al., 2005).

These frontal migrations, as best identified from the scatter of SST data, imply a shift in the ACC. However, any such shift poses a problem because the path of the modern current is steered by the abyssal bathymetry (e.g., Rintoul et al., 2001). Thus, at the LGM it was only the surface waters of the ACC that responded to the shift of the westerly winds and expanded northwards. Overall, the ACC would have slowed down in the LGM compared to modern circulation, which has narrowed and intensified as zonal winds migrate south to reside almost directly above the ACC (e.g., Toggweiler and Russell, 2008). Nevertheless, the glacial ACC may have accelerated locally where its path was restricted by shallow bathymetry (as it is today), to block and compress the advancing fronts (e.g., Pudsey and Howe, 1998).

\section{Responding to millennial change}

Ice cores reveal frequent abrupt changes in temperature (e.g., EPICA, 2004). Of these, the Antarctic Cold Reversal (ACR; 14.2-12.4 kyr) has received recent attention (e.g., Carter et al., 2008). In Antarctica, the ACR is represented by an abrupt cooling of $\sim 3^{\circ} \mathrm{C}$, accompanied by an expansion of ice shelves and sea ice, and a modest intensification of winds (Fig. 2). The response of the surface ocean was variable. South of the Subtropical Front, SSTs cooled in phase with the ACR. This change reflects 


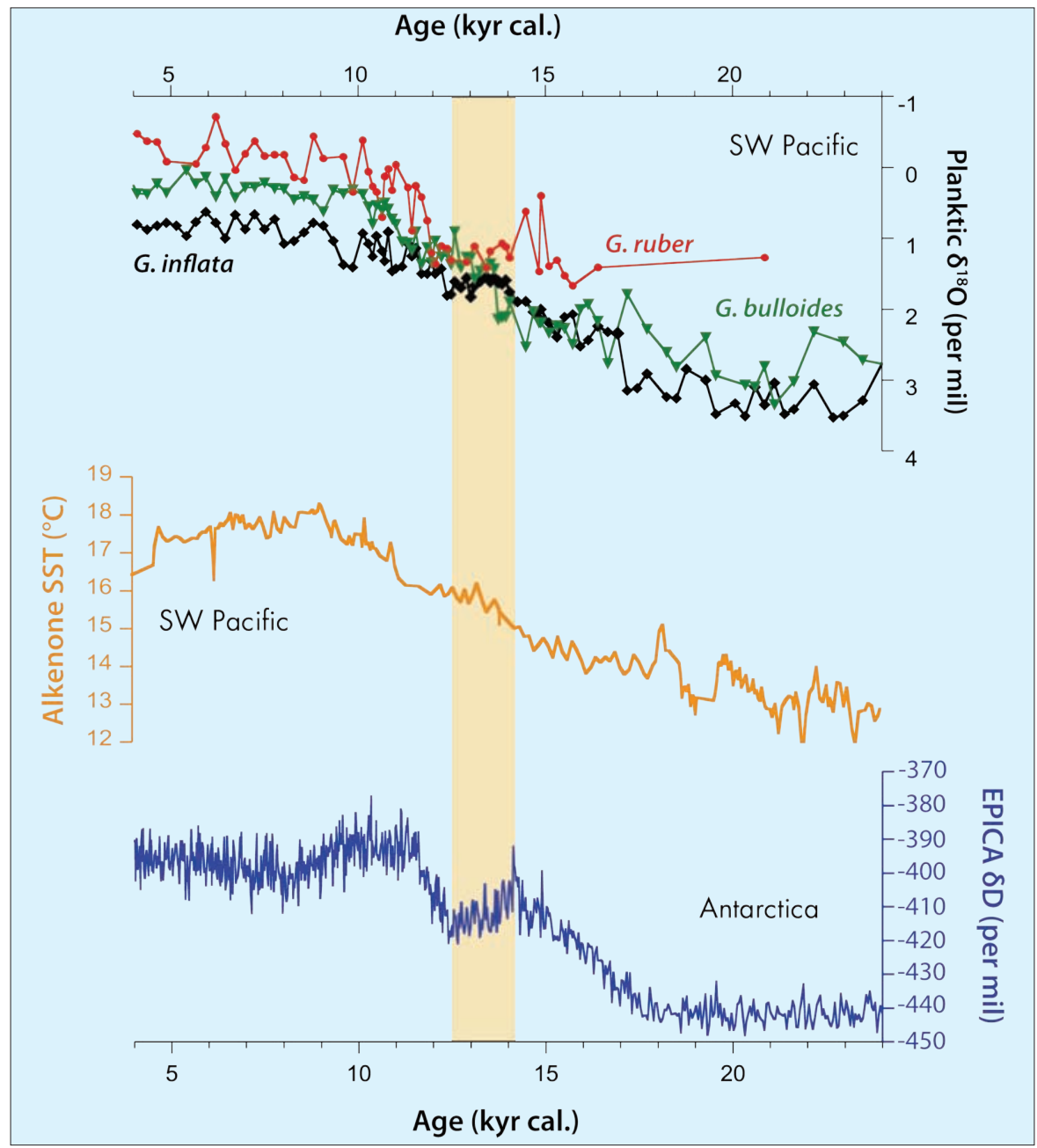

Figure 2: Oxygen isotope profiles from 3 planktic foraminifers (Carter et al., 2008) and an alkenone-based SST curve (Pahnke and Sachs, 2006) spanning the last termination, as recorded in the SW Pacific core, MD97 2121 (see Fig. 1). Yellow shading indicates the Antarctic Cold Reversal (ACR), as identified in the EPICA Dome C ice core deuterium record (EPICA, 2004). The ACR leads any response in the SW Pacific Ocean, where surface waters appear to become better mixed or subject to cooler summers (as suggested by merging of the planktic $\delta^{18} \mathrm{O}$ profiles), and the SST warming trend becomes less pronounced midway through the ACR.

the direct atmospheric and oceanic links with Antarctica, especially during glacial periods when winds and polar waters migrated north. In contrast, waters just north of the Subtropical Front, had a delayed and muted response. Off eastern New Zealand, there was no clear reaction until

$\sim 13.5 \mathrm{kyr}$, when the ACR was at its coldest (Fig. 2). SSTs reduced, marine fertility declined and the uppermost ocean was either more mixed or the thermocline more shallow. Like the SW Pacific Ocean, the S. Indian Ocean also cooled out of phase; SSTs reduced by $0.8^{\circ} \mathrm{C}$ between $13.2-12$

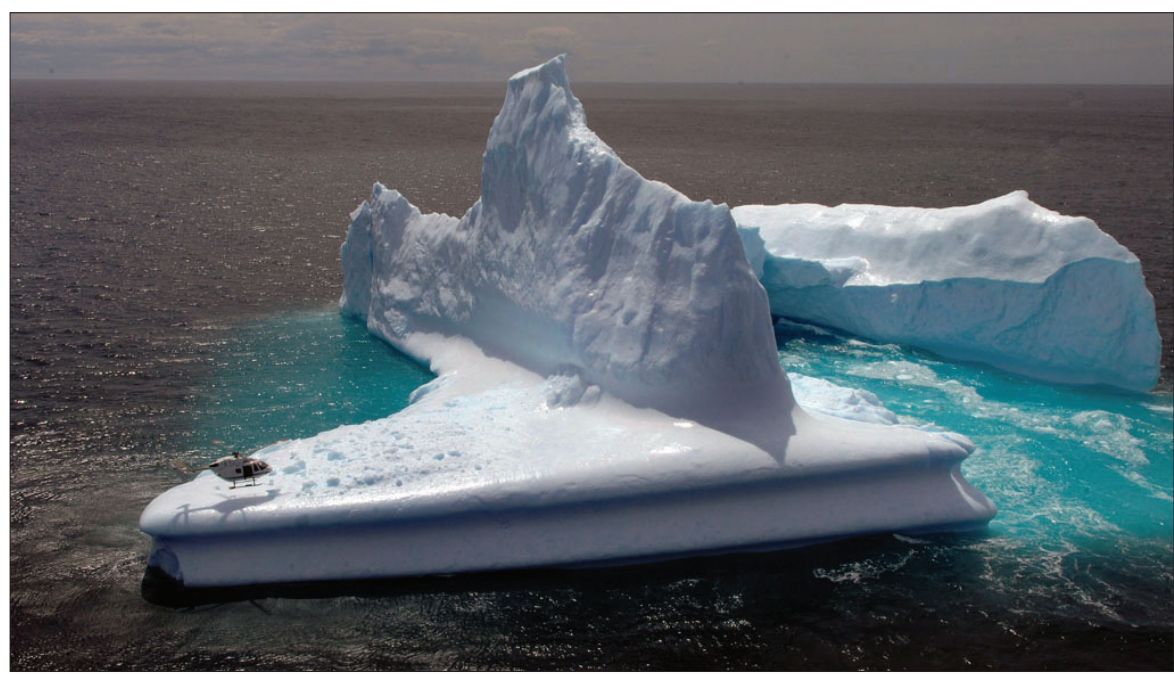

Figure 3: An iceberg sails close to New Zealand in 2006. Whereas the media heralded this as a precursor of global warming, iceberg incursions to this region have occurred throughout recorded history and, of course, during G-I cycles. Image: Stephen Jaquiery, permission for use kindly given by Helicopters Otago (www.helicoptersotago. co.nz/air_transport_ops.html) kyr, about 1 kyr after the ACR began (Stenni et al., 2001). Such reactions suggest distinct regional responses to the ACR. It also seems that reversal events such as the ACR are a feature of glacial terminations (transitions from glacial to interglacial state) around the Southern Ocean, as they appear at several times in the past implying a two-step termination process (Cortese et al., 2007; Bianchi and Gersonde, 2002).

Rapid warm events, recorded by ice cores, are also expressed in SSTs. Antarctic warm events $A 1-4$, between 60-38 kyr, were accompanied by concomitant SST increases of $2-3^{\circ} \mathrm{C}$ (Barrows et al., 2007). Of note is the timing of these warm periods. They appear to immediately precede Dansgaard-Oeschger events 8, 12, 14 and 17 as identified in the Greenland GISP 2 ice core. A north-south connection is also suggested by phases of algal productivity off eastern New Zealand that occurred within 1-2 kyr of iceberg influxes in the N. Atlantic Ocean associated with Heinrich Events 1-6 (Sachs and Anderson, 2005). Therefore, in addition to strong Antarctic influences on the Southern Ocean, there also appear to be links with the northern hemisphere, although the driving mechanism(s) and precise timing of these changes are still being resolved.

\section{The icebergs cometh}

The most dramatic manifestation of Antarctica in the Southern Ocean are icebergs-a point highlighted by the media interest in an iceberg grounded off New Zealand in 2006 (Fig. 3). However, this event was not unusual. Ships have recorded icebergs in mid-southern latitudes since the $19^{\text {th }}$ century. Likewise, sediment cores document pulses of ice rafted debris (IRD) throughout the Quaternary (e.g., Cowan, 2002). A 300 kyr-long record from the Weddell Sea (a prominent source of icebergs) shows IRD deposition was highest in interglacial periods (Grobe and Mackensen, 1992). Further afield, late Quaternary IRD profiles from New Zealand resemble the Weddell Sea records (Carter et al., 2003), which is not surprising as New Zealand intercepts the ACC; the main transporter of icebergs. However, the interglacial IRD pulses in distal records off New Zealand are more subdued than those from the Weddell Sea; a feature attributed to iceberg melting in warm interglacial seas. In contrast, glacial records from the two regions are more closely related, indicating better preservation of icebergs on account of cold ocean temperatures. Superimposed on the G-I cycles are IRD pulses of millennial frequency, which may be traced through much of the Southern Ocean, at least for the past 
70 kyr. Kanfoush et al. (2000) noted that IRD pulses in the S. Atlantic Ocean coincided with warm periods when production of North Atlantic Deep Water (NADW) was enhanced in the northern hemisphere and sea level rose; both processes leading to destabilization of Antarctic ice shelves and the promotion of icebergs.

This brief synthesis of Southern Ocean research highlights the interactions of the atmosphere, ocean and cryosphere of the two hemispheres as they vie for control of the climate machine. It is an exciting challenge to clarify these inter-relationships in order to understand how the planet "ticks" and so to better gauge its responses to a rapidly changing climate.

\section{Note}

The majority of data presented in this article comes from existing datasets available in the World Ocean Circulation Experiment Southern Ocean Atlas (http://wocesoatlas.tamu.edu/)

\section{References}

Barrows, T.T., Juggins, S., de Deckker, P., Calvo, E. and Pelejero, C., 2007: Long-term sea surface temperature and climate change in the Australian-New Zealand region, Paleoceanography, 22: PA2215, doi.10.1029/2006PA001328.

Carter, L., Manighetti, B., Ganssen, G. and Northcote, L., 2008: SW Pacific modulation of abrupt climate change during the Antarctic Cold
Reversal -Younger Dryas, Palaeogeography, Palaeoclimatology, Palaeoecology, 260: 284-298.

Cortese, G., Abelmann, A. and Gersonde, R., 2007: The last five glacialinterglacial transitions: a high-resolution 450,000 year record from the subantarctic Atlantic, Paleoceanography, 22: PA4203, doi:10.1029/2007PA001457.

Gersonde, R., Crosta, X., Abelmann, A. and Armand, L., 2005: Sea surface temperature and sea ice distribution of the Southern 0 cean at the EPILOG Last Glacial Maximum - a circum-Antarctic view based on siliceous microfossil records, Quaternary Science Reviews, 24 869-896.

Howard, W.R. and Prell, W.L., 1992: Late Quaternary surface circulation of the Southern Indian 0cean and its relationship to orbital variations, Paleoceanography, 7: 79-117.

For full references please consult:

www.pages-igbp.org/products/newsletters/ref2009_1.html

\section{New records of the role of Antarctic ice sheets in late Cenozoic climate}

\section{Ross Powell ${ }^{1}$, T. Naish ${ }^{2}$, R. LeVY ${ }^{3}$ And the MIS SCIENCE TEAm ${ }^{3}$}

'Department of Geology and Environmental Geosciences, Northern Illinois University, DeKalb, USA; ross@geol.niu.edu

${ }^{2}$ Antarctic Research Centre, Victoria University of Wellington, New Zealand, and Geological and Nuclear Sciences, Lower Hutt, New Zealand; ${ }^{3}$ ANDRILL Science Management Office, University of Nebraska at Lincoln, USA

\section{New drill core records of Plio-Pleistocene age from Antarctica include evidence of significant changes in ice sheet regime younger than $14 \mathrm{Myr}$ and an obliquity-driven dynamic marine-based ice sheet prior to 800 kyr.}

Although Antarctica's ice sheets contain the world's largest terrestrial water reservoir, their influence on Late Cenozoic (14 Myr ago) sea level and climate remains poorly known from proximal records. Consequently, the role of Antarctica's ice sheets in global sea level and climate relies heavily upon inferences from oxygen isotope records from deep-sea cores. Although these isotopic records have revolutionized our understanding of climate-ice-ocean interactions, questions remain about the specific contribution of Antarctica's ice sheets.

Various lines of evidence, including geomorphic studies from the Transantarctic Mountains (TAM), suggest that the East Antarctic Ice Sheet (EAIS) has been quite stable for the past $14 \mathrm{Myr}$ (Sugden et al., 1993). However, oxygen isotope records indicate moderate oscillations of global ice volume capable of producing sea level fluctuations of $<25 \mathrm{~m}$ above present, prior to the development of northern hemisphere ice sheets about 3 Myr ago. These ice volume changes must have involved a Greenland ice cap, the West Antarctic Ice Sheet (WAIS), and margins of EAIS. A more dynamic view of the late Cenozoic EAIS has been proposed from a number of on-land geological studies, with evidence (from marine diatoms in glacial sediments) of marine incursions into the continental East Antarctica during the Pliocene (5.3-1.8 Myr ago) requiring a significant deglaciation of the interior of EAIS (Webb et al., 1984; Har- wood et al., 2000). However, the origin of the diatoms has been called into question (e.g., McKay et al., 2008), and uncertainty remains over the scale of Antarctic ice sheet dynamism. While this debate continues, the Early and middle Pliocene (5-3 Myr ago) is generally regarded as a time of global warmth and is, therefore, an important window into Earth's future climate in the context of anthropogenic warming.

During the austral summer of 20062007, a new Antarctic geological drilling program (ANDRILL) recovered a 1285-mlong record of climate and ice sheet variability spanning the past $14 \mathrm{Myr}$. This AND$1 \mathrm{~B}$ core came from beneath the 85 -m-thick McMurdo Ice Shelf (MIS), within an 850-mdeep sedimentary basin surrounding Ross Island (Fig. 1). The core provides the best direct evidence of past Antarctic Ice Sheet (AIS) and climate fluctuations for this time interval, enabling comparison with deepsea isotope records, low-latitude continental margin sea level records, and numerical climate and ice sheet models, especially for times of past global warmth. A synopsis of the initial results from AND-1B (Naish et al., $2007 ; 2008$ ) is presented here, focusing on their potential to improve our knowledge of Antarctica's influence on, and response to, global climate change.

\section{Glacial-Interglacial cycles from the MIS Project}

Strata of AND-1B core accumulated in deep water (200-1000 m), $100 \mathrm{~km}$ from the
Victoria Land coastline, western Ross Sea. The diverse range of rock types represent particular past environments that included open marine diatomites (rock made from siliceous diatom remains), mudstones and turbidites (deposits formed by instantaneous downslope movement of sediment) deposited during interglacials from local sources, ice-proximal massive and stratified diamictites (poorly sorted conglomerate), and conglomerates and sandstones representing glacial periods. During glacial periods, the ice sheet had an extensive marine terminus perhaps hundreds of km north of the drill site in the Ross Sea. During interglacials, the drill site was either covered by an ice shelf (similar to present day) or lay in open or sea-ice-covered seas, while the ice sheet had retreated onto the continent with deposition of marine diatoms or terrigenous mud from local streams, and occasional debris from icebergs.

A preliminary age model for the upper $700 \mathrm{~m}$ of drill core constructed from diatom biostratigraphy and radiometric ages on volcanic material allows a unique correlation between about $40 \%$ of the magnetic polarity stratigraphy and the geomagnetic polarity timescale. The age model provides several well-constrained intervals displaying relatively rapid $(<1 \mathrm{~m} / \mathrm{kyr}$ ) and continuous accumulation of sediment, punctuated by several 0.5-1 Myr stratal hiatuses representing more than half of the past $7 \mathrm{Myr}$. Thus, the AND-1B record provides several highly resolved "windows" into late Ceno- 